\section{On health needs: the concept labyrinth}

Sobre as necessidades de saúde: um labirinto conceitual

Sobre las necesidades en salud: un laberinto conceptual
Kenneth Rochel de Camargo Jr. 1

doi: 10.1590/0102-311X00113717

\begin{abstract}
This study aims to reflect on the intertwining of certain key ideas about what we call "health" within the hegemonic biomedical paradigm: health, disease, is based on the philosophical contributions of Heller and Wiggins on needs; on the discussion of some authors, especially Canguilhem, about health and illness; and Collins' sociology of expertise. After pointing out some of the conundrums that arise from the conceptual fluidity of the topics abovementioned, we present a path forward, based on Collins' proposals about the role of ex-

\author{
Correspondence \\ K. R. Camargo Jr. \\ Departamento de Planejamento e Administração em Saúde, \\ Centro Biomédico, Universidade do Estado do Rio de Janeiro. \\ Rua São Francisco Xavier 524, 7o andar, Bloco D, Rio de \\ Janeiro, RJ 20559-900, Brasil. \\ kenneth@uerj.br \\ 1 Centro Biomédico, Universidade do Estado do Rio de Janeiro, \\ Rio de Janeiro, Brasil.
} perts in political arguments, to resituate the discussion on health needs.

Health Services Needs and Demand; Philosophy; Science 


\section{Trapped in the conceptual web}

This study is a reflection on the articulation between some central ideas for discussing what we call "health" within the hegemonic biomedical paradigm. One initial problem is the intertwining of these ideas, which makes it difficult to explore each one in isolation, while addressing all at once is, evidently, impossible. The process I have adopted is to take certain key ideas and discuss them based on relevant authors, so that they may be later articulated to one another. This is a partial discussion, given the limits of the isolated discussion of concepts that are part of a theoretical-conceptual whole. Health, disease, health needs, medicalization and medical-industrial complex are the interwoven themes I will address.

There is, evidently, a historical and geographical delimitation to this discussion. What one thinks of health is inevitably contingent and, in this article, I will direct this discussion toward health thinking in contemporary industrial society, marked by the hegemony of what could be called a biomedical paradigm ${ }^{1}$, also present in the discourse on prevention ${ }^{2}$. There is also a point of view: my perspective is anti-essentialist, in line with Rorty's neopragmatism, and would likely be described by Hacking as a "reformist constructionism" 3 , that is, which seeks, by criticizing certain scientific constructions, to show their historical contingency and to propose alternative perspectives that are more desirable from ethical and political points of view.

This is a theoretical discussion with practical consequences. If one assumes that there is a set of legitimate needs that must be addressed by some social response, it follows that accurately determining when such response is necessary or not is a fundamental operation. Pushing interventions when they are not strictly necessary or not providing them when they do are two obviously unwanted outcomes. Thus, having clear demarcation criteria of what "health needs" consist of is clearly desirable for policy making and general health care management.

This article is divided in four sections. The first two are an analysis of the key elements of the expression "health needs"; the first section addresses the attempts to formally define health, since the paradigm that this discussion comprises is inextricably tied to definitions of disease, often in a tautological bind. The second section addresses the philosophical definition of "need", looking at the contribution of two contemporary philosophers who systematically discussed the concept. Both sections intend to show the inherent difficulty of achieving purely formal definitions of either term of the expression, which will always be subjected to social and historical contingencies. The third section ties together the two key components and articulates them with the socioeconomic structures that mediate the determination of social needs and the responses to them in industrialized societies, acknowledging the role of the medical-industrial complex in this process and the issue of medicalization as a consequence of the possibility of ever expanding "health needs". The fourth and final section resorts to Collins' sociology of expertise as a possible way out for the conundrums that arise from a purely philosophical attempt to frame the subject.

\section{Health and disease}

"Health" and "disease", as "time" was to Augustine, are terms we all believe to know until the moment we are asked to define them. As a philosophical reflection, Georges Canguilhem's 4 contribution is still current and unsurpassed, though the debate concerning the "normal and pathological" continues today 5,6. The attempt to escape from the double tautology of a definition of health and disease as each other's absence has a considerable history, detailed by Canguilhem in the conference La Santé: Concept Vulgaire et Question Philosophique 7. Canguilhem shows how many authors over the years addressed health as the unsaid, culminating in Leriche's motto (which he had already largely discussed 4 ) that health is "life lived in the silence of the organs".

This definition, somehow cast through an absence as well, has been eclipsed by the definition adopted by the World Health Organization (WHO): "Health is a state of complete physical, mental, and social well-being and not merely the absence of disease or infirmity" ${ }^{8}$. Criticized both for being defined by an absence of disease in its second part (the so-called "negative definition") and by the imprecision and, ultimately, unattainability of its first part (the so-called "positive definition"), this definition, 
however, indicates a political objective. This creates another problem, one also discussed by Canguilhem in the already-mentioned conference; after quoting Artaud, he comments: "We are far from a health measured by devices. We will call this health: free, not conditioned, not counted. This free health is not an object on which one may claim, or believe, to be a health expert" 7 (p. 62).

We can note that the field of application of the health concept is confused with the ethical-aesthetic project of a "good life", an association made by Canguilhem himself, and thereby it is not and cannot be under the rule of experts. What remains is therefore the paradox of a "health" which must be placed outside the control of the so-called "health" professions, and certainly outside any panopticon, belonging or not to the State.

The same difficulty in establishing a formal meaning for "disease" is well characterized by Giovanni Berlinguer's book 9 (p. 19): "many definitions, few certainties". To him, there is a multiplicity of components in the term: "in the disease phenomenon, when one considers the human species, three components are interconnected: a) an objective, bodily fact, that is, an alteration is some organ, tract, system or function that is more or less demonstrable; $b$ ) a greater or lesser awareness of the harm; $c$ ) an idea and a measurement, derived from the knowledge, preconceptions and judgments of the time; and therefore a value judgment, an ethical, and not only scientific, interpretation, that works as a guide to action" 9 (p. 20). He further states that, to the sick individual, the phenomenon has four dimensions: being sick (having alterations in the body); feeling sick (perceiving these modifications); identifying the disease (diagnosing it according to the individual's knowledge and the time); and being able to be sick (being able to admit one is sick).

Canguilhem proposes that life itself is polarity, a constant struggle to stay ahead of the "infidelities of the milieu", recalling that the idea of "pathology" exists only in life sciences. He criticizes the traditional distinction normal/pathological on both sides: neither is pathology the absence of norms, nor does "the normal" define what is healthy. Based on this, he proposes the concept of normativity as a fundamental operator, that is, an organism's capacity to rewrite its own norms according to existing conditions. Being sick means being subjected to a norm that is inferior because it is more restrictive and less able to adapt to new circumstances. In the Les Maladies conference, Canguilhem goes further and radically states that disease is a universal biological fact 7 .

This statement contradicts the idea that Canguilhem somehow adopted a vitalist position, but represents, at first glance, a problem for a non-essentialist approach. Is this not an affirmation of an essence of disease? Even if this was Canguilhem's original intention, we may translate this proposition in a way that is compatible with the general perspective I have adopted in this article. We could say that the definition of disease within biomedicine requires a description that is coherent with the general rules for validating knowledge within biology, therefore, one that may be described through the vocabulary of molecules, cells, mechanisms, causes and effects.

But this conception is still largely ignored by the mainstream medical thinking. Possibly because of its pragmatic, action-oriented nature, an abstract definition of disease matters less than the mapping of concrete nosological entities. Still, one may abstract general characteristics that are relevant to think about issues related to health service demands and that underlie the so-called clinical reasoning. Though implicit, one may describe a modern concept of disease 1. Two concepts, lesion and cause, are crucial in medical reasoning, so much that the absence of a verifiable lesion may be taken as the absence of disease tout court, frequently delegitimizing the suffering of the person who claims to be sick, seen as someone who only imagines herself/himself to be sick or, even worse, feigns illness 10 .

The historical development of medical knowledge generated a collection of disease definitions. This collection is also a classification system, materialized in the International Classification of Diseases (ICD), an inventory organized by the WHO, which is already in its tenth revision ${ }^{11}$. A product of a classification apparatus of which medical diagnosis is an important component 12 , and arbitrary, as are all taxonomies, it nonetheless has important social effects (all the medical, legal and clerk machinery of records, compensations and justifications necessarily include it) and is a useful way of organizing knowledge. As Berlinguer notes, "an interpretative scheme that enables pathological phenomena to be regrouped is useful, even if it is still imperfect, biased or fanciful” 9 (p. 118).

The production of medical knowledge on disease, therefore, may be considered a process of constructing and refining this taxonomy, which is always open to being transformed. The introduction of new technologies may lead to the revision of established categories, the introduction of new categories or their regrouping, as has happened more than once in the history of medicine. On the other 
hand, the act of diagnosing may be seen as the attempt to locate individual instances within the limited space of the nosological grid. This localization is the product of practices - and, therefore, expertises - that involve diverse actors, and patients themselves, in what Mol calls enactment 13.

\section{The philosophy of needs}

In this section, I will explore the concept of needs from a philosophical point of view. The starting point is the study of Agnes Heller and David Wiggins, two philosophers who investigated the subject. Both Wiggins 14 and Heller ${ }^{15}$ point to the importance of the notion of needs in Marx's oeuvre, while also acknowledging he did not properly provide a definition of this notion.

Heller addresses the subject of needs at two moments, with significant differences between them. In her first study 15 , she seeks to articulate a concept of needs based on Marx. She draws attention to the existence of multiple definitions and to their complexity. According to Heller, they are not just economic categories, but "anthropological categories of value, and are therefore not susceptible to definition within the economic system" 15 (p. 26). A crucial issue for Heller is the distinction between "natural" and "social" needs 15, which is modified over the course of Marx's oeuvre 15. An initial issue in this discussion is that social needs are not "imaginary" or false; this is a historically and culturally contingent value judgment 15 . This an important point to which I will return later.

Heller analyzes the situations in which needs may be "manipulated" (quotation marks in the original), connecting them with the dynamics of capitalism 15 . She further dedicates a relatively extensive part of her study to the idea of "radical needs", ultimately those originating in human labour 15.

As she revisits the discussion on this subject 16, we can note some differences in the theoretical démarche adopted by Heller. After presenting a thesis that could perfectly fit within her previous study - that by reaching the level of "correct consciousness" individuals would be able to substitute "imaginary" needs for "real" ones (quotation marks in the original) -, Heller discards it in what seems a break with the Marxist perspective she had previously adopted, stating that the "previous line of reasoning suffers from the theoretical deficiency of placing the judge (the theoretician) outside the world that is judged" 16 (p. 58).

Heller divides the critique of the idea that it is possible to distinguish between real and false needs in three aspects: ontological, ethical and political.

From an ontological point of view, the starting point is the critique of the idea that the operator of the value judgment performing this division is outside the realm where this opposition operates, which would create an unsurmountable problem: "When the non-reality of needs is explained through a theory of manipulation, the knowledge of the theoretician who carries out the judgment can only have its origin in the fact that her/his consciousness was not fetishized, that it is 'the' correct consciousness. But how does the theoretician know that hers/his is 'the' correct consciousness?" 16 (p. 58).

This distinction would imply an impossible objectification, given the historical and, therefore, contingent nature of human needs. The risk of this classification is incurring in some form of dictatorship, in which something or someone has the power to define which needs must be considered real. Heller concludes that all human needs must be considered real 16. This perspective imposes the question: is it possible to satisfy all needs defined? In current societies there are always more needs than may be satisfied, thus the establishment of priorities may not be based on the real/imaginary antinomy, but on a system that institutionalizes the decision through a public democratic debate 16 .

From an ethical point of view, the distinction is between good and bad needs, which cannot be mapped over the real/imaginary opposition - "real" needs are not necessarily "good" ones 16. A similar question is asked here: who should decide which needs are good or bad? Turning to Kant's categorical imperative, which has a restrictive character in evaluating needs, Heller states that those which impede all needs from being recognized and satisfied cannot be recognized as needs: no man may be the mere instrument of another. Therefore, if an individual's needs require the negation of another's needs, they are bad and must not be recognized as such 16 .

Finally, from the political point of view, Heller approaches the distinction she attributes to Sartre between manque (awareness of the existence of a need) and projet (awareness of the ways of satisfying a need) 16 . According to her, the problem is that the power structure of all societies inherently contains 
the preference for concrete systems of needs, which enables the targeting of systems of needs, that is, their manipulation 16 .

The solution for the problems raised in these three dimensions, also according to Heller, is the idea of radical needs. In an appropriation unlike that of her previous study, Heller states that Marx attributes radical needs to those who transcend societies based on subordination and hierarchy, who would establish a "society of associated producers", moving away from the strict and univocal connection between these needs and the world of human labor.

Social movements seeking to satisfy these radical needs are constantly arising (Heller cites, among other examples, the feminist movement). Radical needs are plural and thus presuppose a pluralist system of needs 16. According to Heller, "If a radical movement wants to make people happy against its will, it stops being radical (...) [The] option for alternative systems of need may have influence in only one way creating objectivations and institutions such that they include counter-alternatives to those in existence and that therefore guarantee the possibility that needs that only exist as manque become projets" 16 (p. 79).

However, Heller presents two caveats: despite this pluralism, the fact that there is no single way of guiding needs does not mean they may not be criticized; and the source of new systems of needs may not be the State in a pluralist society 16 .

Wiggins's starting point is the connection between needs and rights, which, according to him, is less obvious than may appear at first glance. He emphasizes the importance of the notion of "need" to the political debate, despite the lack of clear definition of the term, and proposes a formalization of the idea of need 14 (p. 10):

$$
\begin{gathered}
\text { "I need [absolutely] to have } x \\
\text { if and only if } \\
\text { I need [instrumentally] to have } x \text { if I am to avoid being harmed } \\
\text { if and only if }
\end{gathered}
$$

It is necessary, things being what they actually are, that if I avoid being harmed then I have x".

Despite the formal definition, Wiggins relativizes the conditions he proposed by acknowledging that what is considered harm is up for debate, relative to a given culture and even to personal conceptions, in addition to vary over time, though, as Heller also states in her second formulation, it is possible to create a consensus around what is and is not necessary 14 .

Beyond a binary definition (something is or is not necessary), Wiggins further proposes the importance of qualifying needs, preparing the discussion for the public debate on needs. Needs may be classified as to severity, urgency, basicness, entrenchment (or permanence in the face of variations of a moral threshold for the definition of harm) and substitutability. They define a state of dependence (regarding not being harmed), which requires the use or possession of something 14.

Wiggins goes further in the discussion of how the affirmation of needs is legally and politically recognized (or not), pointing to a shared (social) morality as the evaluation criteria. He further states that the dissociation between this shared morality and a government's political agenda threatens the latter's very legitimacy 14 . Additionally, different individuals' and groups' needs are inevitably in conflict with one another and to the formal definition of need Wiggins adds a principle of limitation from the standpoint of the State's actions, stating that the mere interest or desire of collectives, regardless of how numerous, cannot impede the realization of anyone's vital needs. This principle rests on the articulation between justice, consensus and the government's sense of legitimacy 14 . Similarly to Heller, Wiggins raises the issue of the responsibility for defining needs, and like Heller he concludes in favor of the importance of democratic discussion 14. In the same study, Wiggins quickly addresses the problem of expertise - which will be discussed in another section - in relation to this issue, that is, that it would not be democratic for experts to determine needs, but once there is a democratic consensus about a given need, experts would be called upon to participate in the design of the best ways to satisfy it 14 .

The preceding discussion ends up being somewhat unsatisfactory. It seems clear that a purely formal definition of "need" may not be possible, or even desirable. One may think of essential needs, indispensable to maintain life itself, such as air, water, food. But even these unquestionable needs do not necessarily translate into rights in a capitalist society. On the one hand, one cannot think of human needs only in these terms; is freedom not also a need? More concretely, in places that lack public transportation, is not owning a car a need, albeit an instrumental one, in Wiggins's definition 
(not because one needs the car itself, but because, without it, indispensable displacements are impossible)? How can we decide which needs must or must not be guaranteed by the State? These questions are not answered by abstract reasoning, but only through the concrete exercise of everyday debates and discussions, less through defining "real" and "false" needs and more through deciding which needs should, or should not, be collectively recognized and translated into a language of rights.

Need, as Health in Canguilhem's discussion in the article La Santé: Concept Vulgaire et Question Philosophique 7, may be best understood as a "vulgar concept", that is, not as trivial, but as within everyone's reach, in alignment with the common thread of the two authors discussed above, who ultimately point to the primacy of the public, democratic debate for the critical analysis and determination of priorities for the different needs.

\section{Health needs, medical-industrial complex and medicalization}

The articulation between these concepts was first proposed by Eduardo Navarro Stotz's doctoral dissertation 17 , which has similar objectives to this study, though with far greater depth and with a very different approach, based on Marxism. He arrives nevertheless at similar conclusions, such as their inescapably social (and, I add, therefore political) nature: "it is not a concept that may be deduced either from an isolated, free individual, abstracted from their concrete social relations, or from the social structure" 17 (p. 129).

This also makes them historically contingent: "Health needs are individual human needs, but, concretely, they are also distorted and hidden, not recognized, just and unjust needs, because they are such in a historically given society" 17 (p. 136).

The problem here is that, since health needs are inevitably social and historical, in a capitalist society they will also inevitably be articulated at several points with the accumulation of capital. The term "medical-industrial complex" and later variations 18 have been used in descriptions and criticisms of these articulations. The existence of an entire economic sector in contemporary society which extracts profits from the production of goods and services target at the health sector is undeniable; the criticism is related to the possibility of manipulating different aspects of this sector for obtaining even greater profits, for example, by manipulating the price of medications that are indispensable to certain groups for maintaining health or even life, or seeking, through questionable means, to increase the number of people who should undergo some intervention, thus increasing the consumption of their product. The latter operation would therefore involve the increasing expansion of what the term "health needs" encompasses. Many call this process medicalization (including the already cited Stotz 17 , see p. 154-5).

This definition includes an a priori moral judgment, unlike the one adopted by Conrad 19 , according to whom medicalization is the process of transforming problems not previously considered to be "medical" (or "health" problems, I would add) into medical problems, usually as disorders or diseases. This definition enables us to imagine medicalization processes that are not condemnable, such as the creation of AIDS as a diagnostic category, which is part of a process that led to prevention and treatment actions that significantly improved the perspectives of controlling the pandemic and enabled a considerably longer survival for those affected by it. Current conceptions of medicalization also fail to address processes that take place outside the confines of health services, but that, in the name of a vague idea of "health", mobilize an increasingly diversified and voluminous "wellness" market 20.

Given the semantic instability of the term, it may be better to adopt the terms proposed by Moynihan: overdiagnosis and overtreatment 21. These terms have the advantage of describing more precisely the phenomena we intend to analyze, in addition to separate two aspects of the process which may operate independently of one another. I would also add the notion of overprevention, the uncontrollable search for a (perfectly unattainable) perfect health and, at the same time, the fearful avoidance of all risk.

The combination of these processes, stimulated by commercial interests (which are included in what Conrad calls the "engines of medicalization"), have an impact on what society will consider a "health need", and it also represents a conceptual problem: how can we determine which "needs" are legitimate, or at least justifiable, if we already assume that it is impossible to satisfactorily draw this 
distinction on the conceptual plane, and assuming their historical and conceptual over-determination? An attempt to answer this question leads us to the discussion on expertise and its social and political role.

\section{Vanishing point: the issue of expertise}

As we have seen, "need" and "health" are difficult terms to capture through a formal network of concepts. Worse, they are ideas that tend toward an expansion ad infinitum; practically any aspect of human life may be encompassed by these categories, let alone by the articulation between the two. As they may mean anything, as concepts they are worthless.

The attempt to paradoxically circumscribe and increasingly broaden what the term "health needs" encompasses points to something impossible and undesirable from a political standpoint; impossible, since it is impossible to satisfy something that is always expanding, and undesirable, since we run the risk of enabling a limitless Foucauldian monitoring and control of all aspects of life, since everything is "health", and this health "needs" everything 22.

Let us therefore imagine an alternative path by considering the usefulness of a non-reified notion of disease, accepted not as an ontological essence, but as a heuristic resource, which designates a certain type of suffering that necessarily involves, d'après Canguilhem, some type of biological compromise, without its understanding and therapeutic being restricted to this perspective. We could think of "health needs" as those that are indispensable for preventing treatment of diseases, following Wiggins's reasoning, which circumscribes a considerably narrower scope of action upon individuals and collectivities 22 .

One problem still persists: who should decide what those needs are and, consequently, how to ensure they are met for the entire population? If we accept they are in fact needs in a strong sense, they generate rights, and as such we must guarantee that they are met. If we admit, like Heller and Wiggins, that there is no possible technocratic delimitation of this issue, on the other hand, we must recognize that no society would bear an unlimited expansion of what is proposed as a health need, which would lead to undesirable consequences, such as the acceptance of therapeutic propositions that are demonstrably innocuous or even harmful to health, though popular 23,24,25.

This dilemma points to the discussion by Collins \& Evans 26 on the role of expertise and science in society; how to avoid the undesirable extremes of a political discussion limited to scientific experts, which he calls "technological fascism", or, in the opposite extreme, a political discussion that completely ignores any merit of scientific arguments, which he calls "technological populism"? His answer begins with a historical overview of science studies: in what he calls the "first wave", that of the sociology of the Mertonian science, the content of science itself is not questioned, but the context in which scientists work is studied, highlighting certain values that guide scientific research (communism, universalism, disinterest, organized skepticism). The second wave, which follows paths established especially by Kuhn's study, questions the epistemic privilege of science and its monopoly on truths regarding the natural world, unveiling it as a human activity. More robust solutions for the collective problems on which science is called upon to comment would be obtained by incorporating broader perspectives into the decision-making process. A new problem then arises; the second wave proposes no limits to participation, creating the illusion that any individual could participate on equal footing in scientific debates. This, according to these authors, generated interpretation errors that led philosophers and social scientists to support proposals that are completely opposed to what "good science" defends, such as considering "intelligent design" to be legitimate science or uncritically supporting anti-vaccine movements. The third wave, that of expertise studies, enables us to draw limits, while admitting the need to recognize other forms of expertise than the academic 27.

Collins \& Evan's proposal is that the contributions of science should be recognized not through criteria of efficacy, but rather through moral criteria; recognizing that its regulatory ideals (listed by Merton and a few others) are the best bet we have to address problems that arise in their domains; though the final word should come from legitimate democratic leaders, scientists should always be heard. They propose a kind of advisory committee comprising "hard" scientists capable of having a critical view of science itself and social scientists engaged in the social study of science, which would 
be able to determine the scientific consensus regarding a given theme and to present alternatives to decisions and their consequences to the political authority. This authority could choose not to consider what these advisors propose, but it would have to be transparent and not hide behind subterfuges; one of the negative examples the authors cite is that of Thabo Mbeki, who used arguments widely rejected by the scientific community as if they were scientific to refuse treatment for people with HIV and AIDS in his country during his presidency 27.

Returning to the issue of health, this means that legitimate needs are not characterized simply because someone believes (s)he needs an MRI, or because certain groups advocate that all conceivable forms of therapy (and at times even the inconceivable ones) must necessarily be covered by health insurance or, worse, taken over by public health care systems. The proposition that every request for health interventions should be complied with no matter what is clearly unsustainable, both technically and economically. Thus, we require the work of experts, health professionals and researchers and people with the experiential expertise of living with certain health problems - the biggest example is still that of HIV/AIDS activists who have historically made crucial contributions to confront the epidemic 28 - for the proposition, implementation and monitoring of health policies and also for meeting individual demands for care. This would happen, for example, in the evaluation of technologies in general and through designing diagnostic and therapeutic protocols, which should have a broadened scope of experts without giving up the critical examination of what is offered as a diagnostic or therapeutic intervention, minimizing the effects of external interests in the outcome of the process; here we must consider not only the widely-known strategies of the pharmaceutical companies, for example, but also the interested advocacy of several kinds of so-called "alternative" therapies, which should not determine the result of critical evaluations. Returning to the beginning of this article, we must recognize within contemporary medicine the existence of a collection of diseases and collectively validated therapeutic approaches that are relatively stable, though permanently subject to revision, which offers the possible (attainable) security for health interventions - to Collins \& Pinch, "the best bet" 28 . We further need to recognize that the expertise needed for debates concerning this collection of knowledge requires a considerable investment of time not only in the acquisition of formal knowledge, but also in the social actions related to practices sanctioned by this type of knowledge, which usually means a professional training that creates contributing experts, capable both of discussing and acting within this reference point, though one may gain discursive competence for effectively participating in the discussion, as an interactional expert 26 . To put it bluntly, spending some hours googling for medical terms, for instance, does not make a health expert.

It is this collaborative work that will enable us to avoid the excesses of overdiagnosis, overtreatment and overprevention, fed by diverse (especially commercial) interests, while also extending as much as possible services that meet needs for care, so that individuals threatened by suffering related to disease are not abandoned to their fate or left at the mercy of supposed therapeutic interventions that are often innocuous at best. The critical reflection regarding what are "health needs", therefore, far from being an idle intellectual exercise, is an imperative for adequately structuring health care.

\section{Acknowledgments}

To Rio de Janeiro State University (UERJ)/Brazilian Nacional Research Council (CNPq)/Rio de Janeiro State Research Foundation (Faperj) for the financial support.

\section{References}

1. Camargo Jr. KR. O paradigma clínico-epidemiológico ou biomédico. Revista Brasileira de História da Ciência 2013; 6:183-95.

2. Arouca S. O dilema preventivista: contribuição para a compreensão e crítica da medicina preventiva. São Paulo: Editora Unesp; 2003. 
3. Hacking I. The social construction of what? Cambridge: Harvard University Press; 1999.

4. Canguilhem G. Le normal et le pathologique, augmenté de nouvelles réflexions concernant le normal et le pathologique. Paris: Presses Universitaires de France; 1966.

5. Gaudenzi P. Normal e patológico no naturalismo e no normativismo em saúde: a controvérsia entre Boorse e Nordenfelt. Physis (Rio J.) 2016; 26:747-67.

6. Sholl J. Escaping the conceptual analysis straitjacket: pathological mechanisms and Canguilhem's biological philosophy. Perspect Biol Med 2015; 58:395-418.

7. Canguilhem G. Écrits sur la médecine. Paris: Seuil; 2002.

8. World Health Organization. Preamble to the Constitution of the World Health Organization as adopted by the International Health Conference, New York, 19-22 June, 1946; signed on 22 July 1946 by the representatives of 61 States and entered into force on 7 April 1948. (Official Records of the World Health Organization, 2). http://apps.who.int/gb/bd/PDF/bd47/EN/ constitution-en.pdf.

9. Berlinguer G. A doença. São Paulo: Centro Brasileiro de Estudos de Saúde/Editora Hucitec; 1988.

10. Guedes CR, Nogueira MI, Camargo Júnior KR. Os sofredores de sintomas indefinidos: um desafio para a atenção médica? Physis (Rio J.) 2009; 19:797-815.

11. World Health Organization. International statistical classification of diseases and related health problems. Geneva: World Health Organization; 2004.

12. Bowker GC, Starr SL. Sorting things out: classification and its consequences. Cambridge: MIT Press; 2000.

13. Mol A. The body multiple: ontology in medical practice. Durham: Duke University Press; 2002.

14. Wiggins D. Needs, values, truth: essays in the philosophy of value. 3rd Ed. Oxford: Oxford University Press; 1998.

15. Heller A, Ivars J-F, Rovatti PA. Teoría de las necesidades en Marx. Barcelona: Península; 1986.

16. Heller A, Rivero A. Una revisión de la teoría de las necesidades. Barcelona: Paidós; 1996.
17. Stotz EN. Necessidades de saúde: mediações de um conceito [Doctoral Dissertation]. Rio de Janeiro: Escola Nacional de Saúde Pública, Fundação Oswaldo Cruz; 1991.

18. Mendonça ALO, Camargo Jr. KR. Complexo médico-industrial/financeiro: os lados epistemológico e axiológico da balança. Physis (Rio J.) 2012; 22:215-38.

19. Conrad P. The medicalization of society: on the transformation of human conditions into treatable disorders. Baltimore: JHU Press; 2008.

20. Camargo Jr. KR. Medicalização, farmacologização e imperialismo sanitário. Cad Saúde Pública 2013 ; 29:844-6.

21. Moynihan R, Henry D, Moons KG. Using evidence to combat overdiagnosis and overtreatment: evaluating treatments, tests, and disease definitions in the time of too much. PLoS Med 2014; 11:e1001655.

22. Camargo Jr. KR. As armadilhas da "concepção positiva de saúde”. Physis (Rio J.) 2007; 17:63-76.

23. Nisse P, Guyodo G, Manel J. Evaluation des risques liés à la consommation de produit dénommé "Solution Minérale Miracle" (MMS). http:// www.centres-antipoison.net/CCTV/Rapport_ CCTV_Solution_minerale_miracle_2010.pdf (accessed on 03/Jun/2017).

24. Yun YH, Lee MK, Park SM, Kim YA, Lee WJ, Lee KS, et al. Effect of complementary and alternative medicine on the survival and health-related quality of life among terminally ill cancer patients: a prospective cohort study. Ann Oncol 2013; 24:489-94.

25. Nortier J, Pozdzik A, Roumeguere T, Vanherweghem J-L. Aristolochic acid nephropathy ("Chinese herb nephropathy"). Nephrol Ther 2015; 11:574-88.

26. Collins H, Evans R. Rethinking expertise. Chicago: University of Chicago Press; 2007.

27. Collins H, Evans R. Why democracies need science. Hoboken: John Wiley \& Sons; 2017.

28. Collins H, Pinch T. Dr. Golem: how to think about medicine. Chicago: University of Chicago Press; 2008. 


\section{Resumo}

O estudo visa refletir sobre o entrelaçamento entre determinadas ideias-chave sobre o que denominamos "saúde" dentro do paradigma biomédico hegemônico: saúde, doença, necessidades de saúde, medicalização e complexo médico-industrial. A reflexão tem como base os aportes filosóficos de Heller e Wiggins sobre necessidades; a discussão de alguns autores, notadamente Canguilhem, sobre saúde e adoecimento e a sociologia da expertise, de Collins. Depois de identificar alguns dos dilemas que surgem da fluidez conceitual dos temas mencionados acima, apresentamos um caminho para estudos futuros, com base nas propostas de Collins sobre o papel dos experts nos argumentos politicos, para recolocar a discussão sobre necessidades de saúde.

Necessidades e Demandas de Serviços de Saúde; Filosofia; Ciência

\section{Resumen}

Este estudio tiene como meta reflejar la interrelación de ciertos conceptos clave a los que consideramos "salud", dentro del paradigma biomédico hegemónico: salud, enfermedad, necesidades de salud, medicalización y complejo médico-industrial. Esta reflexión está basada en las contribuciones filosóficas de Heller y Wiggins sobre las necesidades; sobre la discusión de algunos autores, especialmente Canguilhem, sobre salud y enfermedad; y la sociología de las capacidades de Collins. Tras señalar algunos de los dilemas que surgen, procedentes de la fluidez conceptual de los temas anteriormente mencionados, presentamos el camino a seguir, basado en las propuestas de Collins sobre el papel de los expertos en las discusiones politicas, con el fin de reubicar la discusión sobre las necesidades en el ámbito de la salud.

Necesidades y Demandas de Servicios de Salud; Filosofía; Ciencia
Submitted on $03 / \mathrm{Jul} / 2017$

Final version resubmitted on $26 / \mathrm{Feb} / 2018$

Approved on 06/Mar/2018 